\title{
Triiodothyronine improves age-induced glucose intolerance and increases the expression of sirtuin- 1 and glucose transporter-4 in skeletal muscle of aged rats
}

\author{
Sahar M. El Agaty \\ Physiology Department, Faculty of Medicine, Ain Shams University, Cairo, Egypt
}

\begin{abstract}
To evaluate the potential beneficial impact and to clarify the underlying mechanisms of triiodothyronine $\left(\mathrm{T}_{3}\right)$ on glucose intolerance in aged rats. Rats were divided into adult group, aged group, and $\mathrm{T}_{3}$-treated aged group ( $\mathrm{T}_{3}$-aged). $\mathrm{T}_{3}$ was administered at a dose of $8 \mu \mathrm{g} / \mathrm{kg}$ body weight for 2 weeks. In comparison to adult group, aged rats presented significant higher levels of fasting insulin and homeostatic model assessment of insulin resistance (HOMA-IR). Glucose area under the curve (AUC), and peak glycemia, estimated from oral glucose tolerance curve, were significantly increased along with decreased mRNA expression of skeletal muscle sirtuin-1, glucose transporter-4 (GLUT-4) and uncoupling protein-3 (UCP-3) in aged versus adult group. $\mathrm{T}_{3}$ administration significantly decreased the serum levels of fasting insulin, HOMA-IR, glucose AUC, and peak glycemia in $\mathrm{T}_{3}$-aged versus aged rats. Skeletal muscle mRNA expression of sirtuin- 1 and GLUT-4 were increased, whereas UCP- 3 was not changed by $\mathrm{T}_{3}$ administration. $\mathrm{T}_{3}$ administration improved glucose intolerance, and decreased insulin resistance in aged rats. This was associated with upregulation of skeletal muscle sirtuin-1 and GLUT-4 which could mediate such beneficial effect.
\end{abstract}

Key words: Triiodothyronine - Aging - Glucose intolerance - Skeletal muscle - Sirtuin-1

\section{Introduction}

Glucose tolerance increasingly deteriorates with advancing age leading to high prevalence of impaired glucose tolerance and type 2 diabetes in elderly (Moreno et al. 2010). Such impairment is primarily due to decline in insulin sensitivity associated with diminished glucose utilization by peripheral tissues (Akintola and van Heemst 2015). Because skeletal muscle quantitatively is the main site of insulin responsive glucose uptake and metabolism (DeFronzo et al. 1981), the age-related maladaptive events in skeletal muscles may contribute partly to the observed insulin resistance (IR) in elderly populations.

Silent information regulator-1 (sirtuin-1, SIRT-1), $\mathrm{NAD}+$-dependent protein deacetylase, is found in many tissues and is considered as a key metabolic regulator because it causes deacetylation of a wide range of protein

Correspondence to: Sahar Mohamed El Agaty, 24 Mohamed El Makaref street, Nasr city, Cairo, Egypt

E-mail: sahar_elagaty@yahoo.com
substrates(Haigis and Sinclair, 2010). It has a crucial role in glycemic control via activating pathways involved in cellular energy metabolism, glucose uptake, and glucose production inhibition (Hardie 2013). Recent researches have concluded that during aging, decreased expression of SIRT-1 in skeletal muscle fundamentally mediates IR (Pardo and Boriek 2011), whereas, increased SIRT1 expression restrains age associated-diabetes (Yoshino et al. 2011), and enhances insulin sensitivity (Banks et al. 2008). Moreover, both human (Houmard et al. 1995), and animal studies (Mohamed et al. 2014) have reported a decline in the skeletal muscle glucose transporter-4 (GLUT-4) with aging. GLUT-4 is a glucose-transport protein that increases the cellular uptake of glucose and, therefore involves the whole body glucose homeostasis (Canto and Auwerx 2010). Additionally, uncoupling protein-3 (UCP-3), one of the family of inner mitochondrial membrane proteins that uncouple mitochondrial respiration (Koshkin et al. 2004), is highly expressed in skeletal muscles and is able to increase glucose utilization rate (Krook et al. 1998). The levels of this protein have been also shown to decline with age (Kerner 
et al. 2001). Early treatment of age-related IR is crucial for alleviating or preventing the hyperglycemic complications and decreasing the costs of medical care

Thyroid hormones have an important physiological role in glucose metabolism of almost all body cells. These functions are mediated by activating the nuclear transcription of large numbers of genes that further stimulate the synthesis of protein enzymes, structural proteins, and transport proteins (Brenta 2010). Although both hyperthyroidism and hypothyroidism have been related to disturbances in insulin signaling and glucose metabolism (Teixeira et al. 2012), exogenous thyroid hormone administration in IR and glucose intolerance conditions have recently attracted considerable attention with favorable outcomes. Accumulating recent reports have shown that exogenous triiodothyronine $\left(\mathrm{T}_{3}\right)$ administration can decrease glycemia and improve insulin signaling in diabetic (Prieto-Almeida et al. 2018) and obese rats (Panveloski-Costa et al. 2018). It has been also demonstrated that $\mathrm{T}_{3}$ is able to enhance insulin-stimulated glucose transport and glycolysis in skeletal muscles (Moreno et al. 2011). Interestingly, Vazquez-Anaya et al. (2017) reported an improvement of glucose intolerance and IR by thyroxine $\left(\mathrm{T}_{4}\right)$ treatment in obese rats. Vazquez-Anaya and colleagues attributed these beneficial effects to the capability of $\mathrm{T}_{4}$ to upregulate the expression of SIRT-1 and UCP-2 in skeletal muscle. On the other hand, a number of studies have failed to show a protective effect of thyroid hormone against glucose intolerance. Lambadiari et al. (2011) have investigated the effect of variations in thyroid hormone plasma levels (within the normal euthyroid range) on insulin sensitivity in humans and they recorded a positive relationship between high levels of thyroid hormone and IR. The authors added, thyroid hormone plays a role in mediating metabolic derangement early in diabetes. Similarly, in another human study Jing et al. (2014) recorded an increase in the prevalence of impaired fasting glucose and glucose intolerance in association with high free $\mathrm{T}_{3}$ levels. This has led to some uncertainty regarding the appropriate recommendation for thyroid hormone use and further studies are required to elucidate the valuable impact of thyroid hormone on glucose intolerance. Thus, the present work was designed to evaluate the potential beneficial effect and the underlying mechanisms of triiodothyronine on glucose intolerance in aged rats.

\section{Materials and Methods}

\section{Animals}

Seven young adult (3-4 month old, body weight $190 \pm 10 \mathrm{~g}$ ) and 14 aged (20-24 month old, body weight $405.2 \pm 22.4 \mathrm{~g}$ ) male Wister rats were obtained from Helwan Farm, Cairo, Egypt. Rats were maintained under regular 12 h/12 h day/ night cycle in the Medical Research Center, Faculty of Medicine, Ain Shams University. Rats were fed standard rat chow and allowed free access to food and water. All experimental procedures were carried out according to the guidelines of FMASU, REC (Faculty of Medicine, Ain Shams University, Research Ethics Committee, Cairo, Egypt) which conforms to the Guide for the Care and Use of Laboratory Animals published by United States National Institute of Health.

\section{Experimental design}

Rats were divided randomly into three groups: 1 ) adult group ( $n=7$; rats received intraperitoneal (i.p.) injection of the hormone vehicle); 2) aged group ( $n=7$; rats received i.p. of the hormone vehicle), and 3) $\mathrm{T}_{3}$-aged group ( $n=7$; triiodothyronine-treated aged group - rats received 3,3,5-triiodo-Lthyronine) (Sigma, St. Louis, MO, USA) which was dissolved in $1 \mathrm{~N}$ of $\mathrm{NaOH} /$ isotonic saline and given i.p. at a dose of $8 \mu \mathrm{g} /$ $\mathrm{kg}$ body weight per day for 2 weeks) (Vazquez-Anaya et al. 2017). Body weight was measured at the beginning $\left(\mathrm{BW}_{1}\right)$ and at the end $\left(\mathrm{BW}_{2}\right)$ of the experiment. On $13^{\text {th }}$ day an overnight fasting started at 9 p.m. On the $14^{\text {th }}$ day an oral glucose tolerance test (OGTT) was performed in overnight fasted rats at 9 a.m. then rats were allowed free access to food and water and at 9 p.m. the overnight fasting started again. On the $15^{\text {th }}$ day, at 9 a.m. the rats were weighed and injected intraperitoneally with sodium thiopental $(40 \mathrm{mg} / \mathrm{kg}$ ). A midline abdominal incision was made, the abdominal aorta was exposed and cannulated with a polyethylene catheter, and a blood sample was collected in a plastic tube. Blood was allowed to coagulate, at room temperature, centrifuged at $3000 \mathrm{rpm}$ for $15 \mathrm{~min}$ and serum was stored at $-20^{\circ} \mathrm{C}$, till used for estimation of serum levels of free triiodothyronine $\left(\mathrm{FT}_{3}\right)$, fasting glucose and insulin levels. The gastrocnemius muscle was extracted for determination of GLUT-4, UCP-3, and SIRT-1.

\section{Oral glucose tolerance test}

OGTT was performed in overnight fasted rats as previously described by (Okada et al. 2017). Rats received $1 \mathrm{~g} / \mathrm{kg}$ glucose by gavage and rats' blood samples were taken intermittently from the tails and glucose levels were measured with a glucometer (Glucostar, Medland Co., Middle East. Gulf \& Africa).

\section{Analytical procedures and data analysis}

The glucose area under the curve was calculated by trapezoid method (Purves 1992). Peak glycemia was calculated from OGTT. The homeostatic model assessments (HOMA) for determining IR was calculated according to Zhou et al. (2006) as follow: HOMA-IR (a measure for IR) $=$ [fasting insulin $(\mathrm{mU} / \mathrm{l}) \times$ fasting glucose $(\mathrm{mg} / \mathrm{dl}) \times 0.0555] / 22.5$. 


\section{Biochemical analysis}

Fasting serum glucose was measured using oxidase-peroxidase method (Trinder 1969). Serum levels of insulin and $\mathrm{FT}_{3}$ were analyzed using enzyme-linked immunosorbent assay ELISA (Dako, Carpinteria, CA, and Cusabio, USA, respectively) according to the manufacturer's instructions.

\section{Detection of relative gene expression by real time PCR}

\section{Total RNA extraction}

Total RNA was extracted from tissue homogenate using SV Total RNA Isolation System (Promega, Madison, WI, USA) according to manufacturer's instruction. The RNA concentrations and purity were measured with an ultraviolet spectrophotometer.

\section{Complementary DNA (cDNA) synthesis}

The cDNA was synthesized from $1 \mu \mathrm{g}$ RNA using Super Script III First-Strand Synthesis System as described in the manufacturer's protocol (\#K1621, Fermentas, Waltham, MA, USA). In brief, $1 \mu \mathrm{g}$ of total RNA was mixed with $50 \mu \mathrm{M}$ oligo (dT) $20,50 \mathrm{ng} / \mu \mathrm{l}$ random primers, and $10 \mathrm{mM}$ dNTP mix in a total volume of $10 \mu$ l. The mixture was incubated at $56^{\circ} \mathrm{C}$ for $5 \mathrm{~min}$, and then placed on ice for $3 \mathrm{~min}$. The reverse transcriptase (RT) master mix containing $2 \mu$ of $10 \times \mathrm{RT}$ buffer, $4 \mu \mathrm{l}$ of $25 \mathrm{mM} \mathrm{MgCl}_{2}, 2 \mu \mathrm{l}$ of $0.1 \mathrm{M} \mathrm{DTT}$, and $1 \mu \mathrm{l}$ of Super Script ${ }^{\circledast}$ III RT $(200 \mathrm{U} / \mu \mathrm{l})$ was added to the mixture and was incubated at $25^{\circ} \mathrm{C}$ for $10 \mathrm{~min}$ followed by $50 \mathrm{~min}$ at $50^{\circ} \mathrm{C}$.

\section{Real-time quantitative PCR}

Real-time PCR amplification and analysis were performed using an Applied Biosystem with software version 3.1 (Step One $^{\mathrm{m}}$, USA). The reaction contained SYBR Green Master Mix (Applied Biosystems), gene-specific primer pairs were designed with Gene Runner Software (Hasting Software, Inc, Hasting, NY) from RNA sequences from the gene bank. All primer sets had a calculated annealing temperature of $60^{\circ} \mathrm{C}$. Quantitative RT-PCR was performed in a $25-\mu \mathrm{l}$ reaction volume consisting of 2X SYBR Green PCR Master Mix (Applied Biosystems), $900 \mathrm{nM}$ of each primer and $2 \mu \mathrm{l}$ of cDNA. Amplification conditions were: $2 \mathrm{~min}$ at $50^{\circ} \mathrm{C}$, $10 \mathrm{~min}$ at $95^{\circ} \mathrm{C}$ and 40 cycles of denaturation for $15 \mathrm{~s}$ and annealing/extension at $60^{\circ} \mathrm{C}$ for $10 \mathrm{~min}$. Data from real-time assays were calculated using the v1 7 sequence detection software from PE Biosystems (Foster City, CA). Relative expression of studied gene mRNA was calculated using the comparative Ct method. All values were normalized to beta actin which was used as the control housekeeping gene and reported as fold change over background levels detected in the diseased groups. The sequences of PCR primer pairs used for each gene are listed as follows: SIRT-1 (Forward primer: 5'- TTGGCACCGATCCTCGAAC-3, Reverse primer 5'CCCAGCTCCAGTCAGGAACTAT-3'); UCP-3 (Forward primer :5' - AGAACCATCGCCAGGGAGGAAGGA-3, Reverse primer:5' - CACCGGGGAGGCCACCACTGT-3); GLUT-4 (Forward primer: 5'GAGCCTGAATGCTAATGGAG3', Reverse primer: 5'GAGAGAGAGCGTCCAATGTC3); Beta actin (Forward primer :5'TGTTTGAGACCTTCAACACC-3', Reverse primer:5' CGCTCATTGCCGATAGTGAT-3').

\section{Statistical analysis}

All variables were presented as mean \pm standard deviation (SD). The one-sample Kolmogorov-Smirnov test was used to test for normality of variables and all variables are normally distributed. One way ANOVA was done to determine the differences between groups and in case of significant " $F$ " test $(p<0.05)$, further analysis was made by LSD to find inter-group significance.

\section{Results}

Body weight and serum levels of $\mathrm{FT}_{3}$

As demonstrated in Table 1 , the body weight of $\mathrm{T}_{3}$-aged rats was not significantly different from that of aged group. The serum levels of $\mathrm{T}_{3}$ were significantly higher in $\mathrm{T}_{3}$-aged group compared to aged rats.

\section{Glucose regulation and IR}

In comparison to adult group, aged rats presented significant higher levels of fasting insulin, and HOMA-IR. Also, the fasting glucose was higher in aged versus adult group, though it was statistically insignificant. $\mathrm{T}_{3}$ administration in $\mathrm{T}_{3}$-aged rats decreased the levels of fasting insulin, fasting glucose, and HOMA-IR compared to aged rats. All were statistically significant except for fasting glucose level (Table 1). In comparison to adult group, fasting insulin, and HOMA-IR were still significantly higher in $\mathrm{T}_{3}$-aged rats.

Concerning OGTT, fasting glucose (measured just before the test) was not significantly different between adult and aged groups, though it was higher in aged rats $(96.2 \pm 15.3$ versus $111.7 \pm 2.8)$ (Figure 1$)$. The levels of blood glucose at 30,60, 90, and $120 \mathrm{~min}$ (during OGTT) together with the glucose AUC and the peak glycemia all were significantly elevated in aged rats compared to adult group. $\mathrm{T}_{3}$ administration attenuated the blood glucose levels throughout the OGTT, the glucose AUC, and the peak glycemia in $\mathrm{T}_{3}$-aged rats compared to the untreated 
Table 1. Changes in initial $\left(\mathrm{BW}_{1}\right)$ and final $\left(\mathrm{BW}_{2}\right)$ body weights, serum levels of free triiodothyronine $\left(\mathrm{FT}_{3}\right)$, fasting glucose, fasting insulin, and homeostatic model assessment of insulin resistance (HOMA-IR) in the three study groups

\begin{tabular}{lccc}
\hline & \multicolumn{3}{c}{ Group } \\
\cline { 2 - 4 } & Adult & Aged & $\mathrm{T}_{3}$-Aged \\
\hline $\mathrm{BW}_{1}(\mathrm{~g})$ & $190 \pm 10$ & $405.3 \pm 21.9^{*}$ & $405 \pm 25.4^{*}$ \\
$\mathrm{BW}_{2}(\mathrm{~g})$ & $202.4 \pm 11.5$ & $429 \pm 11.6^{*}$ & $421.3 \pm 18^{*}$ \\
$\mathrm{FT}_{3}(\mathrm{ng} / \mathrm{dl})$ & $2.96 \pm 0.4$ & $2.44 \pm 0.6$ & $3.1 \pm 0.7^{\#}$ \\
Fasting glucose $(\mathrm{mg} / \mathrm{dl})$ & $95.1 \pm 5.6$ & $105 \pm 13.7$ & $95.4 \pm 3.3$ \\
Fasting insulin $(\mathrm{ng} / \mathrm{ml})$ & $1.36 \pm 0.2$ & $1.84 \pm 0.1^{*}$ & $1.62 \pm 0.1^{\star * \#}$ \\
HOMA-IR & $9.8 \pm 2.2$ & $13.6 \pm 0.9^{*}$ & $10.3 \pm 0.4^{\#}$ \\
\hline
\end{tabular}

Data are expressed as mean $\pm \mathrm{SD}, n=7$ per each group; ${ }^{\star} p<0.05 v s$. adult group, ${ }^{\#} p<0.05 v s$. aged group. $\mathrm{T}_{3}$-Aged, triiodothyronine-treated aged group.

aged group. All were statistically significant except for the fasting blood glucose (estimated before the OGTT). In comparison to adult rats, the blood glucose levels at 60 , 90, and $120 \mathrm{~min}$ (during OGTT) together with the glucose AUC and the peak glycemia were still significantly higher in $\mathrm{T}_{3}$-aged rats.

\section{GLUT-4, UCP-3, and SIRT-1}

As presented in Figure 2, SIRT-1, GLUT-4, and UCP-3 were significantly decreased in aged versus adult rats. $\mathrm{T}_{3}$ administration significantly increased GLUT-4 and SITR-1 in $\mathrm{T}_{3}$-aged group compared to aged rats; however, both were still significantly higher in $\mathrm{T}_{3}$-aged group compared to adult group. UCP-3 showed non significant changes in $\mathrm{T}_{3}$-aged versus aged group.

\section{Discussion}

The main finding of the present study was the attenuation of glucose intolerance and IR along with enhancement of insulin sensitivity by $\mathrm{T}_{3}$ administration in aged rats. Skeletal muscle levels of SIRIT-1 and GLUT-4 expression were also increased and proposed as possible mechanisms mediating such favorable metabolic effects. Moreover, UCP-3 expression in skeletal muscle was not significantly affected by $\mathrm{T}_{3}$ administration.

The results of the present study revealed a significant increase in HOMA-IR in aged versus adult rats, implying high IR. This finding was further supported by the significant fasting hyperinsulinemia in aged rats which seems to be a compensatory mechanism to maintain glucose homeostasis in light of high IR (Chang and Halter 2003). Additionally, the glucose clearance was slower in aged versus adult rats, so that the glucose AUC as well as the peak glycemia were significantly higher in aged group. These findings agree with previous studies (Moreno et al. 2010) and point to high IR and glucose intolerance in aged rats.

Although the results of fasting glucose were insignificant, they showed a tendency toward impairment of both fasting glucose and glucose tolerance in aged versus adult rats. The fasting glucose in aged rats (whether measured before OGTT $(111.7 \pm 2.8)$ or immediately before sacrifice $(105 \pm$ 13.7)) and the $2 \mathrm{~h}$ glucose obtained by OGTT (149.2 \pm 9.9$)$ approached the values of impaired fasting glucose (fasting glucose $\geq 100 \mathrm{mg} / \mathrm{dl}$ and $<126 \mathrm{mg} / \mathrm{dl}$ ) and impaired glucose tolerance ( $2 \mathrm{~h}$ plasma glucose $\geq 140 \mathrm{mg} / \mathrm{dl}$ and $<200 \mathrm{mg} / \mathrm{dl}$ ) (Zhou et al. 2006), which might point to impaired glucose regulation or prediabetes in aged rats.

Several evidences support the hypothesis that during aging the skeletal muscle is the principle site where the early metabolic disturbances leading to IR take place: 1) Age-associated decrease in the skeletal muscle expression of SIRT-1 (Mohamed et al. 2014), and AMP-activated protein kinase (AMPK) (Qiang et al. 2007) were found to promote IR and glucose intolerance (Jing et al. 2008; Jayanthy et al. 2017). 2) Diminished expression of GLUT-4 in aged skeletal muscle (Larkin et al. 2001) was reported to decrease the capacity of glucose uptake which lead to IR and diabetes (Kern et al. 1992; Stenbit et al. 1996). 3) Lower levels of UCP-3 in aged skeletal muscle (Kerner et al. 2001), were supposed to reduce the glucose utilization rate (Krook et al. 1998). In line with this assumption, the present results showed a downregulation of skeletal muscle levels of SIRT-1, GLUT-4, and UCP-3 mRNA expression in concomitance with significant glucose intolerance and IR in aged versus adult rats.

$\mathrm{T}_{3}$ administration, in the current work, decreased levels of fasting insulin, HOMA-IR, glucose AUC, and peak glycemia in association with upregulation of skeletal muscle SIRT-1 mRNA expression. Such results suggest that $\mathrm{T}_{3}$ administration improves glucose tolerance and IR in aged rats partly via increasing expression of muscle SIRT-1. This inference is in agreement with previous studies (Vazquez-Anaya et al. 
2017). There is a limited number of reports linking $\mathrm{T}_{3}$ and SIRT-1, although SIRT-1 and thyroid receptors similarly influence genes that control gluconeogenesis, lipid oxidation and mitochondrial function (Liu and Brent 2010; Nogueiras et al. 2012).

SIRT-1, through its dependent transduction pathways, is a well established insulin sensitizer (Schenk et al. 2011). It modulates glucose metabolism by influencing insulin signaling (Pulla et al. 2012; Luu et al. 2013). Also, AMPactivated protein kinase (AMPK), is an energy sensor that positively modulates insulin-dependent glucose uptake (Jing et al. 2008). SIRT-1 and AMPK are reported to activate each other and also, have a crucial role in the glycemic control induced by thyroid hormones (de Lange et al. 2008, 2011) Thyroxine is able to upregulate muscle SIRT-1 expression (Vazquez-Anaya et al. 2017), and $\mathrm{T}_{2}$ can activate AMPK either directly (Lombardi et al. 2009) or indirectly via stimulating SIRT-1 (de Lange et al. 2011). Moreover, $\mathrm{T}_{3}$ administration in animal models rapidly phosphorylates and activates AMPK in muscle (Irrcher et al. 2008; Lombardi et al. 2009). The interaction between SIRT-1 and AMPK activates pathways that control cellular energy metabolism, mitochondrial biogenesis and glucose uptake and inhibit glucose production (Hardie 2013). Upregulation of SIRT-1 enhances insulin-stimulated phosphoinositide 3-kinase signaling and glucose uptake, improving insulin sensitivity (Schenk et al. 2011). Also, activation of AMPK phosphorylates insulin receptor substarte-1on Ser-789 which, in turn, enhances insulin signaling (Jakobsen et al. 2001). Accordingly, the ability of $\mathrm{T}_{3}$ to upregulate muscle level of SIRT-1, herein, might be a fundamental path to modulate glucose homeostasis, improving IR.

Another important mechanism by which $\mathrm{T}_{3}$ administration, in the current study, could improve glucose tolerance was the significant increase in GLUT-4 expression in skeletal muscle of $\mathrm{T}_{3}$-aged versus aged rats. This postulate is in accord with previous studies (de Lange et al. 2008). The main cellular mechanism which decreases blood glucose after glucose load is insulin-stimulated glucose transport into skeletal muscle. The principle glucose transporter that mediates this uptake is GLUT-4, hence it is a key determinant of glucose disposal (Larkin et al. 2001). Defective expression of the gene encoding for GLUT-4 in skeletal muscle is one possible mechanism of insulin resistance (Bell et al. 1989). Decreased GLUT-4 mRNA levels was reported in streptozotocin-induced diabetes in rats (Berger et al. 1989; Garvey et al. 1989) and in insulin resistant patients (Dohm et al. 1991). Transgenic ablation of GLUT-4 in muscle also results in insulin resistance

A

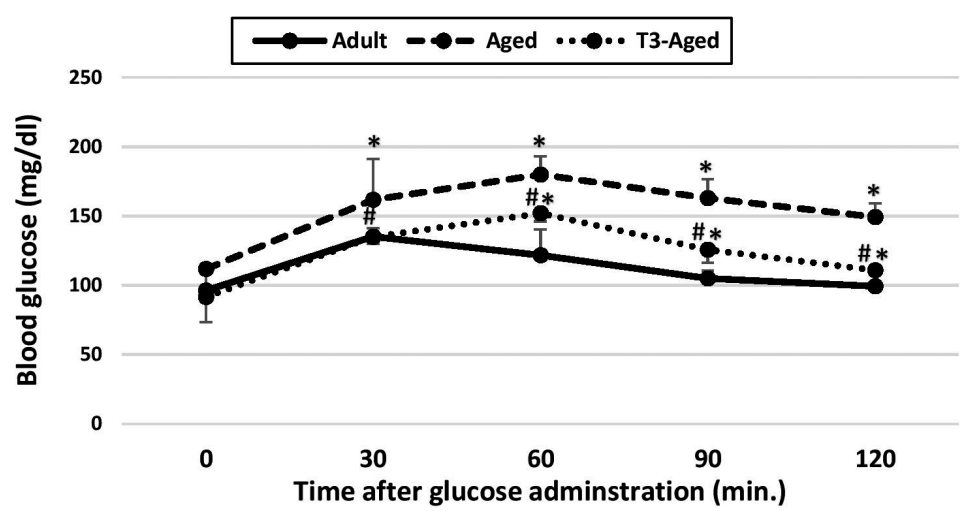

B

\section{Glucose AUC}

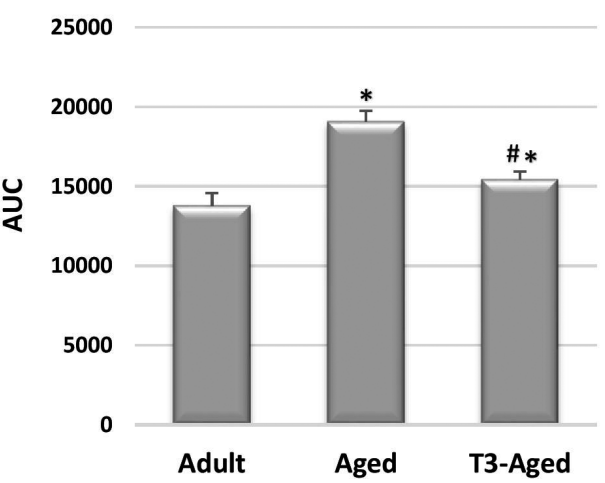

$\mathrm{C}$

Peak glycemia

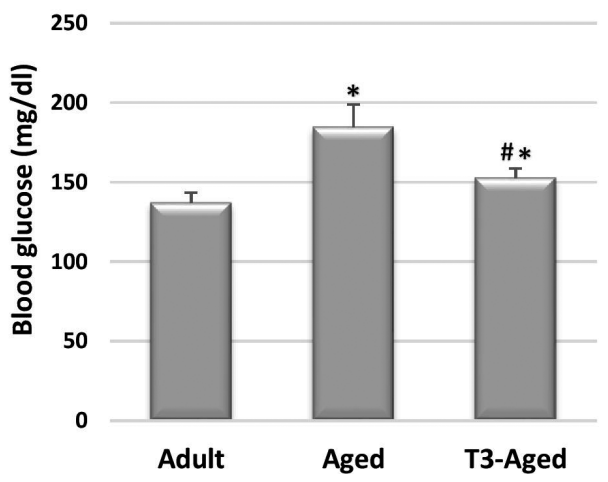

Figure 1. Oral glucose tolerance test $(\mathbf{A})$, area under the curve (AUC, B), and peak glycemia $(\mathbf{C})$ in the three study groups. Data are expressed as mean $\pm \mathrm{SD}, n=7 ;{ }^{\star} p<0.05$ versus adult group, $\# p<0.05$ versus aged group. $\mathrm{T}_{3}$-Aged, triiodothyronine-treated aged group. 
and impaired glucose tolerance (Zisman et al. 2000). Neufer et al. (1993) concluded that decreased rate of synthesis of skeletal muscle GLUT-4 mRNA (gene transcription) mediates insulin resistance in streptozotocin-induced diabetic animals. Moreover, diabetic rats presented severe reduc-
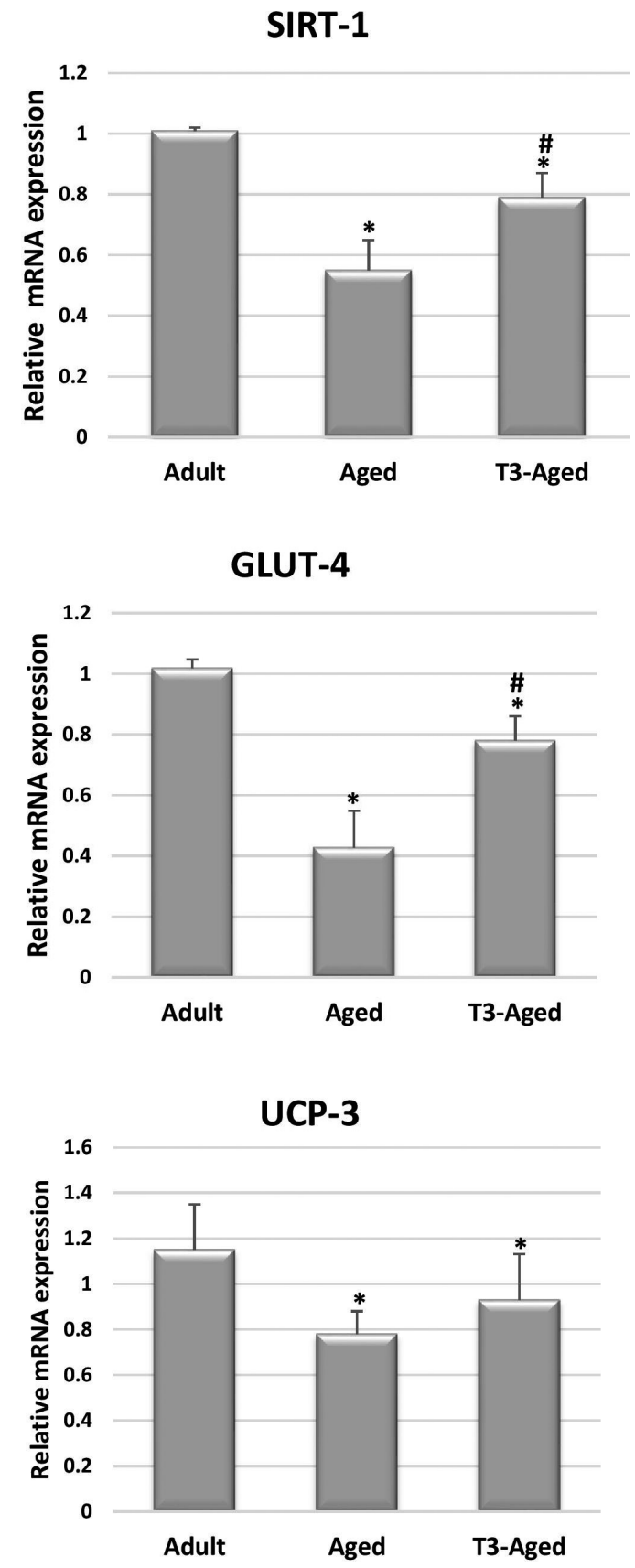

Figure 2. Relative mRNA expression of Sirtuin-1 (SIRT-1), glucose transporter-4 (GLUT-4), and uncoupling protein-3 (UCP-3) in the three study groups. Data are expressed as mean $\pm \mathrm{SD}, n=7 ;{ }^{\star} p<$ 0.05 versus adult group, $\# p<0.05$ versus aged group. $\mathrm{T}_{3}$-Aged, triiodothyronine-treated aged group. tion in glucose transport capacity associated with reduced skeletal muscle GLUT-4 protein content (Barnard et al. 1990). In contrast, the increase in muscle GLUT-4 protein expression enhanced insulin sensitivity in vitro (Charron and Kahn 1990). Furthermore, overexpression of GLUT-4 in muscle of genetically diabetic mice attenuates insulin resistance and promotes glycemic control by increasing both basal and insulin-stimulated glucose transport (Gibbs et al. 1995). Accordingly, these reports denote that skeletal muscle glucose transport is a rate-limiting step for whole body glucose disposal and suggest that the upregulation of GLUT-4 expression in $\mathrm{T}_{3}$-aged group might partly alleviate insulin resistance. The $\mathrm{T}_{3}$-induced upregulation of GLUT-4, herein, might be attributed to the increased muscle SIRT-1 expression which in turn activates AMPK, leading to enhancement of GLUT-4 translocation from intracellular vesicles into the cell membrane (Koistinen et al. 2003).

UCP-3 is an inner mitochondrial membrane protein principally present in brown adipocytes, cardiac and skeletal muscles (Boss et al. 1997; Vidal-Puig et al. 1997). The potential protective effect of UCP-3 in limiting IR is not well understood, although some data suggest a role in the fatty acids metabolism (Khalfallah et al. 2000) as well as in alleviating reactive oxygen species production (Vidal-Puig et al. 2000).

Krool et al. recorded a decrease in skeletal muscle UCP-3 content in the prediabetic state with impaired glucose tolerance (Krook et al. 1998). Moreover, 50\% lower levels of UCP-3 were found in skeletal muscles of type 2 diabetic patient compared to healthy controls (Schrauwen et al. 2001). A direct relationship was demonstrated between the levels of UCP-3 in muscle and the rate of insulin activated glucose utilization (Krook et al. 1998). Transgenic upregulation of UCP-3 in muscles of mice was reported to decrease adiposity, fasting plasma glucose and insulin levels with increased glucose clearance rate (Clapham et al. 2000). $\mathrm{T}_{3}$ administration in the present study non significantly affects the muscle UCP-3 expression in $\mathrm{T}_{3}$-aged versus aged rats. Inconsistent with the present finding, both $\mathrm{T}_{3}$ and $\mathrm{T}_{2}$ upregulated skeletal muscle UCP-3 in hypothyroid rat models (Lanni et al. 1999; de Lange et al. 2001). Hyperinsulinemia is known to suppress the skeletal muscle UCP-3 (Harmancey et al. 2015). Additionally, SIRT-1 can repress the glucocorticoid induced UCP-3 gene expression in skeletal muscle (Amat et al. 2007). Therefore, the inability of $\mathrm{T}_{3}$ administration, herein, to upregulate UCP-3 might be explained by the high fasting insulin and/or the upregulation of SIRT-1 in $\mathrm{T}_{3}$-aged group.

Although 2 weeks of $\mathrm{T}_{3}$ administration ameliorated glucose intolerance and IR in the present study, it did not affect UCP-3 or completely normalize the fasting insulin, glucose AUC, peak glycemia, and muscle expression of GLUT-4, and SIRT-1 in comparison to adult rats. A higher dose and/or longer duration of $\mathrm{T}_{3}$ may be required to fully correct such changes. 
This study has some limitations. Firstly, measurement of heart rate would be helpful to detect the potential development of exogenous hyperthyroidism. However, in the present study there was no detectable decrease in the body weight of $\mathrm{T}_{3}$-aged versus aged rats. Furthermore, the $\mathrm{FT}_{3}$ levels were not significantly different in $\mathrm{T}_{3}$-aged versus adult group. Secondly, performing insulin tolerance test would be convenient to investigate the insulin response to glucose load, particularly the insulin response to oral glucose load was reported to diminish with age(Muller et al. 1996). Thirdly, the use of sodium thiopental in anesthesia might increase insulin secretion from the pancreas (Dou et al. 2012). However, thiopental was given to the 3 study groups and serum levels of fasting insulin showed a significant increase in aged rats versus adult group, and a significant decrease in $\mathrm{T}_{3^{-}}$ aged versus aged rats, notifying a favorable impact of $\mathrm{T}_{3}$ on insulin resistance. Also, the two follow-on overnight fasting procedure might suppress GLUT-4 (Olson 2012). Nevertheless, skeletal muscle mRNA expression of GLUT-4, herein, showed a significant decrease in aged versus adult rats and a significant increase in $\mathrm{T}_{3}$-aged versus aged rats, confirming a role of $\mathrm{T}_{3}$ in upregulating GLUT-4. Fourthly, it would be very suitable to determine plasma membrane GLUT-4 protein under basal and insulin stimulated conditions because they are the best markers of muscle glucose uptake, reflecting the real muscle insulin sensitivity (Olson 2012).

\section{Conclusion}

This study provides evidence to a potential benefit of $\mathrm{T}_{3}$ on glucose homeostasis in the process of aging. The present data show that $\mathrm{T}_{3}$ administration in aged rats significantly improved glucose tolerance, and decreased IR. These might be attributed in part to the upregulation of skeletal muscle SIRT-1, and GLUT-4 mRNA expression. Skeletal muscle UCP-3 mRNA expression is not significantly changed. Further exploration of the proper $\mathrm{T}_{3}$ dose and/or duration, taking into consideration the risk of exogenous hyperthyroidism, could yield more promising results in the process of aging.

Conflict of interest. The author declares that there are no conflicts of interest.

Acknowledgements. The author would like to offer a special thanks to Prof. Laila A. Rashed, Professor of Biochemistry, Faculty of Medicine, Cairo, University.

\section{References}

Akintola AA, van Heemst D (2015): Insulin, aging, and the brain: mechanisms and implications. Front. Endocrinol. 6, 13 https://doi.org/10.3389/fendo.2015.00013
Amat R, Solanes G, Giralt M, Villarroya F (2007): SIRT1 is involved in glucocorticoid-mediated control of uncoupling protein-3 gene transcription. J. Biol. Chem. 282, 34066-34076 https://doi.org/10.1074/jbc.M707114200

Banks AS, Kon N, Knight C, Matsumoto M, Gutierrez-Juarez R, Rossetti L, Gu W, Accili D (2008): SirT1 gain of function increases energy efficiency and prevents diabetes in mice. Cell. Metab. 8, 333-341 https://doi.org/10.1016/j.cmet.2008.08.014

Barnard RJ, Youngren JF, Kartel DS, Martin DA (1990): Effects of streptozotocin-induced diabetes on glucose transport in skeletal muscle. Endocrinology 126, 1921-1926 https://doi.org/10.1210/endo-126-4-1921

Bell GI, Murray JC, Nakamura Y, Kayano T, Eddy RL, Fan YS, Byers MG, Shows TB (1989): Polymorphic human insulin-responsive glucose-transporter gene on chromosome 17p13. Diabetes 38, 1072-1075 https://doi.org/10.2337/diab.38.8.1072

Berger J, Biswas C, Vicario PP, Strout HV, Saperstein R, Pilch PF (1989): Decreased expression of the insulin-responsive glucose transporter in diabetes and fasting. Nature 340, 70-72 https://doi.org/10.1038/340070a0

Boss O, Samec S, Paoloni-Giacobino A, Rossier C, Dulloo A, Seydoux J, Muzzin P, Giacobino JP (1997): Uncoupling protein-3: a new member of the mitochondrial carrier family with tissuespecific expression. FEBS Lett. 408, 39-42 https://doi.org/10.1016/S0014-5793(97)00384-0

Brenta G (2010): Diabetes and thyroid disorders. Br. J. Diabetes vasc. Dis. 10, 172-177

Canto C, Auwerx J (2010): AMP-activated protein kinase and its downstream transcriptional pathways. Cell. Mol. Life Sci. 67, 3407-3423 https://doi.org/10.1007/s00018-010-0454-Z

Chang AM, Halter JB (2003): Aging and insulin secretion. Am. J. Physiol. Endocrinol. Metab. 284, E7-12 https://doi.org/10.1152/ajpendo.00366.2002

Charron MJ, Kahn BB (1990): Divergent molecular mechanisms for insulin-resistant glucose transport in muscle and adipose cells in vivo. J. Biol. Chem. 265, 7994-8000

Clapham JC, Arch JR, Chapman H, Haynes A, Lister C, Moore GB, Piercy V, Carter SA, Lehner I, Smith SA, et al. (2000): Mice overexpressing human uncoupling protein-3 in skeletal muscle are hyperphagic and lean. Nature 406, 415-418 https://doi.org/10.1038/35019082

DeFronzo RA, Jacot E, Jequier E, Maeder E, Wahren J, Felber JP (1981): The effect of insulin on the disposal of intravenous glucose. Results from indirect calorimetry and hepatic and femoral venous catheterization. Diabetes 30, 1000-1007 https://doi.org/10.2337/diab.30.12.1000

De Lange P, Cioffi F, Senese R, Moreno M, Lombardi A, Silvestri E, De Matteis R, Lionetti L, Mollica MP, Goglia F, Lanni A (2011): Nonthyrotoxic prevention of diet-induced insulin resistance by 3,5-diiodo-L-thyronine in rats. Diabetes 60, 2730-2739 https://doi.org/10.2337/db11-0207

De Lange P, Lanni A, Beneduce L, Moreno M, Lombardi A, Silvestri E, Goglia F (2001): Uncoupling protein-3 is a molecular determinant for the regulation of resting metabolic rate by thyroid hormone. Endocrinology 142, 3414-3420 
https://doi.org/10.1210/endo.142.8.8303

De Lange P, Senese R, Cioffi F, Moreno M, Lombardi A, Silvestri E, Goglia F, Lanni A (2008): Rapid activation by 3,5,3'-L-triiodothyronine of adenosine 5 -monophosphate-activated protein kinase/acetyl-coenzyme a carboxylase and akt/protein kinase B signaling pathways: relation to changes in fuel metabolism and myosin heavy-chain protein content in rat gastrocnemius muscle in vivo. Endocrinology 149, 6462-6470 https://doi.org/10.1210/en.2008-0202

Dohm GL, Elton CW, Friedman JE, Pilch PF, Pories WJ, Atkinson SM, Jr, Caro JF (1991): Decreased expression of glucose transporter in muscle from insulin-resistant patients. Am. J. Physiol. 260, E459-463 https://doi.org/10.1152/ajpendo.1991.260.3.E459

Dou HQ, Xu YF, Sun JP, Shang S, Guo S, Zheng LH, Chen CC, Bruce IC, Yu X, Zhou Z (2012): Thiopental-induced insulin secretion via activation of IP3-sensitive calcium stores in rat pancreatic beta-cells. Am. J. Physiol. Cell Physiol. 302, C796-803 https://doi.org/10.1152/ajpcell.00081.2011

Garvey WT, Huecksteadt TP, Birnbaum MJ (1989): Pretranslational suppression of an insulin-responsive glucose transporter in rats with diabetes mellitus. Science 245, 60-63 https://doi.org/10.1126/science.2662408

Gibbs EM, Stock JL, Mccoid SC, Stukenbrok HA, Pessin JE, Stevenson RW, Milici AJ, Mcneish JD (1995): Glycemic improvement in diabetic $\mathrm{db} / \mathrm{db}$ mice by overexpression of the human insulin-regulatable glucose transporter (GLUT4). J. Clin. Invest. 95, 1512-1528 https://doi.org/10.1172/JCI117823

Haigis MC, Sinclair DA (2010): Mammalian sirtuins: biological insights and disease relevance. Annu. Rev. Pathol. 5, 253-295 https://doi.org/10.1146/annurev.pathol.4.110807.092250

Hardie DG (2013): AMPK: a target for drugs and natural products with effects on both diabetes and cancer. Diabetes 62, 2164-2172 https://doi.org/10.2337/db13-0368

Harmancey R, Haight DL, Watts KA, Taegtmeyer H (2015): Chronic hyperinsulinemia causes selective insulin resistance and down-regulates uncoupling protein 3 (UCP3) through the activation of sterol regulatory element-binding protein (SREBP)-1 transcription factor in the mouse heart. J. Biol. Chem. 290, 30947-30961 https://doi.org/10.1074/jbc.M115.673988

Houmard JA, Weidner MD, Dolan PL, Leggett-Frazier N, Gavigan KE, Hickey MS, Tyndall GL, Zheng D, Alshami A, Dohm GL (1995): Skeletal muscle GLUT4 protein concentration and aging in humans. Diabetes $44,555-560$ https://doi.org/10.2337/diab.44.5.555

Irrcher I, Walkinshaw DR, Sheehan TE, Hood DA (2008): Thyroid hormone (T3) rapidly activates p38 and AMPK in skeletal muscle in vivo. J. Appl. Physiol. 104, 178-185 https://doi.org/10.1152/japplphysiol.00643.2007

Jakobsen SN, Hardie DG, Morrice N, Tornqvist HE (2001): 5 '-AMPactivated protein kinase phosphorylates IRS-1 on Ser-789 in mouse $\mathrm{C} 2 \mathrm{C} 12$ myotubes in response to 5-aminoimidazole4-carboxamide riboside. J. Biol. Chem. 276, 46912-46916 https://doi.org/10.1074/jbc.C100483200

Jayanthy, G, Roshana Devi V, Ilango K, Subramanian SP (2017): Rosmarinic acid mediates mitochondrial biogenesis in insulin resistant skeletal muscle through activation of AMPK. J. Cell. Biochem. 118, 1839-1848 https://doi.org/10.1002/jcb.25869

Jing M, Cheruvu VK, Ismail-Beigi F (2008): Stimulation of glucose transport in response to activation of distinct AMPK signaling pathways. Am. J. Physiol. Cell Physiol. 295, C1071-1082 https://doi.org/10.1152/ajpcell.00040.2008

Jing S, Xiaoying D, Ying X, Rui L, Mingyu G, Yuting C, Yanhua Y, Yufan W, Haiyan S, Yongde P (2014): Different levels of thyroid hormones between impaired fasting glucose and impaired glucose tolerance: free T3 affects the prevalence of impaired fasting glucose and impaired glucose tolerance in opposite ways. Clin. Endocrinol. (Oxf) 80, 890-898 https://doi.org/10.1111/cen.12384

Kern M, Dolan PL, Mazzeo RS, Wells JA, Dohm GL (1992): Effect of aging and exercise on GLUT-4 glucose transporters in muscle. Am. J. Physiol. 263, E362-367 https://doi.org/10.1152/ajpendo.1992.263.2.E362

Kerner J, Turkaly PJ, Minkler PE, Hoppel CL (2001): Aging skeletal muscle mitochondria in the rat: decreased uncoupling protein-3 content. Am. J. Physiol. Endocrinol. Metab. 281, E1054-1062 https://doi.org/10.1152/ajpendo.2001.281.5.E1054

Khalfallah Y, Fages S, Laville M, Langin D, Vidal H (2000): Regulation of uncoupling protein-2 and uncoupling protein-3 mRNA expression during lipid infusion in human skeletal muscle and subcutaneous adipose tissue. Diabetes 49, 25-31 https://doi.org/10.2337/diabetes.49.1.25

Koistinen HA, Galuska D, Chibalin AV, Yang J, Zierath JR, Holman GD, Wallberg-Henriksson H (2003): 5-amino-imidazole carboxamide riboside increases glucose transport and cell-surface GLUT4 content in skeletal muscle from subjects with type 2 diabetes. Diabetes 52, 1066-1072 https://doi.org/10.2337/diabetes.52.5.1066

Koshkin V, Bikopoulos G, Chan CB, Wheeler MB (2004): The characterization of mitochondrial permeability transition in clonal pancreatic beta-cells. Multiple modes and regulation. J. Biol. Chem. 279, 41368-41376 https://doi.org/10.1074/jbc.M406914200

Krook A, Digby J, O'rahilly S, Zierath JR, Wallberg-Henriksson H (1998): Uncoupling protein 3 is reduced in skeletal muscle of NIDDM patients. Diabetes 47, 1528-1531 https://doi.org/10.2337/diabetes.47.9.1528

Lambadiari V, Mitrou P, Maratou E, Raptis AE, Tountas N, Raptis SA, Dimitriadis G (2011): Thyroid hormones are positively associated with insulin resistance early in the development of type 2 diabetes. Endocrine 39, 28-32

https://doi.org/10.1007/s12020-010-9408-3

Lanni A, Beneduce L, Lombardi A, Moreno M, Boss O, Muzzin P, Giacobino JP, Goglia F (1999): Expression of uncoupling protein-3 and mitochondrial activity in the transition from hypothyroid to hyperthyroid state in rat skeletal muscle. FEBS Lett. 444, 250-254 https://doi.org/10.1016/S0014-5793(99)00061-7

Larkin LM, Reynolds TH, Supiano MA, Kahn BB, Halter JB (2001): Effect of aging and obesity on insulin responsiveness and glut-4 glucose transporter content in skeletal muscle of Fischer 344 x Brown Norway rats. J. Gerontol. A Biol. Sci. Med. Sci. 56, B486-492 
https://doi.org/10.1093/gerona/56.11.B486

Liu YY, Brent GA (2010): Thyroid hormone crosstalk with nuclear receptor signaling in metabolic regulation. Trends Endocrinol. Metab. 21, 166-173 https://doi.org/10.1016/j.tem.2009.11.004

Lombardi A, De Lange P, Silvestri E, Busiello RA, Lanni A, Goglia F, Moreno M (2009): 3,5-Diiodo-L-thyronine rapidly enhances mitochondrial fatty acid oxidation rate and thermogenesis in rat skeletal muscle: AMP-activated protein kinase involvement. Am. J. Physiol. Endocrinol. Metab. 296, E497-502 https://doi.org/10.1152/ajpendo.90642.2008

Luu L, Dai FF, Prentice KJ, Huang X, Hardy AB, Hansen JB, Liu Y, Joseph JW, Wheeler MB (2013): The loss of Sirt1 in mouse pancreatic beta cells impairs insulin secretion by disrupting glucose sensing. Diabetologia 56, 2010-2020 https://doi.org/10.1007/s00125-013-2946-5

Mohamed JS, Wilson JC, Myers MJ, Sisson KJ, Alway SE (2014): Dysregulation of SIRT-1 in aging mice increases skeletal muscle fatigue by a PARP-1-dependent mechanism. Aging (Albany NY) 6, 820-834 https://doi.org/10.18632/aging.100696

Moreno M, Ordonez P, Alonso A, Diaz F, Tolivia J, Gonzalez C (2010): Chronic 17beta-estradiol treatment improves skeletal muscle insulin signaling pathway components in insulin resistance associated with aging. Age 32, 1-13

https://doi.org/10.1007/s11357-009-9095-2

Moreno M, Silvestri E, De Matteis R, De Lange P, Lombardi A, Glinni D, Senese R, Cioffi F, Salzano AM, Scaloni A, Lanni A, Goglia F (2011): 3,5-Diiodo-L-thyronine prevents high-fatdiet-induced insulin resistance in rat skeletal muscle through metabolic and structural adaptations. FASEB J. 25, 3312-3324 https://doi.org/10.1096/fj.11-181982

Muller DC, Elahi D, Tobin JD, Andres R (1996): Insulin response during the oral glucose tolerance test: the role of age, sex, body fat and the pattern of fat distribution. Aging (Milano) 8,13-21 https://doi.org/10.1007/BF03340110

Neufer PD, Carey JO, Dohm GL (1993): Transcriptional regulation of the gene for glucose transporter GLUT4 in skeletal muscle. Effects of diabetes and fasting. J. Biol. Chem. 268, 13824-13829

Nogueiras R, Habegger KM, Chaudhary N, Finan B, Banks AS, Dietrich MO, Horvath TL, Sinclair DA, Pfluger PT, Tschop MH (2012): Sirtuin 1 and sirtuin 3: physiological modulators of metabolism. Physiol. Rev. 92, 1479-1514 https://doi.org/10.1152/physrev.00022.2011

Okada N, Kobayashi S, Moriyama K, Miyataka K, Abe S, Sato C, Kawazoe K (2017): Helianthus tuberosus (Jerusalem artichoke) tubers improve glucose tolerance and hepatic lipid profile in rats fed a high-fat diet. Asian Pac. J. Trop. Med. 10, 439-443 https://doi.org/10.1016/j.apjtm.2017.03.028

Olson AL (2012): Regulation of GLUT4 and insulin-dependent glucose flux. ISRN Mol. Biol. 2012, 856987 https://doi.org/10.5402/2012/856987

Panveloski-Costa AC, Serrano-Nascimento C, Bargi-Souza P, Poyares LL, Viana GS, Nunes MT (2018): Beneficial effects of thyroid hormone on adipose inflammation and insulin sensitivity of obese Wistar rats. Physiol. Rep. 6, e13550 https://doi.org/10.14814/phy2.13550

Pardo PS, Boriek AM (2011): The physiological roles of Sirt1 in skeletal muscle. Aging (Albany NY) 3, 430-437 https://doi.org/10.18632/aging.100312

Prieto-Almeida F, Panveloski-Costa AC, Crunfli F, Da Silva Teixeira S, Nunes MT, Torrao AS (2018): Thyroid hormone improves insulin signaling and reduces the activation of neurodegenerative pathway in the hippocampus of diabetic adult male rats. Life Sci. 192, 253-258 https://doi.org/10.1016/j.lfs.2017.11.013

Pulla VK, Battu MB, Alvala M, Sriram D, Yogeeswari P (2012): Can targeting SIRT-1 to treat type 2 diabetes be a good strategy? A review. Expert. Opin. Ther. Targets 16, 819-832 https://doi.org/10.1517/14728222.2012.703656

Purves RD (1992): Optimum numerical integration methods for estimation of area-under-the-curve (AUC) and area-underthe-moment-curve (AUMC). J. Pharmacokinet. Biopharm. 20, 211-226 https://doi.org/10.1007/BF01062525

Qiang W, Weiqiang K, Qing Z, Pengju Z, Yi L (2007): Aging impairs insulin-stimulated glucose uptake in rat skeletal muscle via suppressing AMPKalpha. Exp. Mol. Med. 39, 535-543 https://doi.org/10.1038/emm.2007.59

Schenk S, Mccurdy CE, Philp A, Chen MZ, Holliday MJ, Bandyopadhyay GK, Osborn O, Baar K, Olefsky JM (2011): Sirt1 enhances skeletal muscle insulin sensitivity in mice during caloric restriction. J. Clin. Invest. 121, 4281-4288 https://doi.org/10.1172/JCI58554

Schrauwen P, Hesselink MK, Blaak EE, Borghouts LB, Schaart G, Saris WH, Keizer HA (2001): Uncoupling protein 3 content is decreased in skeletal muscle of patients with type 2 diabetes. Diabetes 50, 2870-2873 https://doi.org/10.2337/diabetes.50.12.2870

Stenbit AE, Burcelin R, Katz EB, Tsao TS, Gautier N, Charron MJ, Le Marchand-Brustel Y (1996): Diverse effects of Glut 4 ablation on glucose uptake and glycogen synthesis in red and white skeletal muscle. J. Clin. Invest. 98, 629-634 https://doi.org/10.1172/JCI118833

Teixeira SS, Tamrakar AK, Goulart-Silva F, Serrano-Nascimento C, Klip A, Nunes MT (2012): Triiodothyronine acutely stimulates glucose transport into L6 muscle cells without increasing surface GLUT4, GLUT1, or GLUT3. Thyroid 22, 747-754 https://doi.org/10.1089/thy.2011.0422

Trinder P (1969): Determination of blood glucose using 4-amino phenazone as oxygen acceptor. J. Clin. Pathol. 22, 246 https://doi.org/10.1136/jcp.22.2.246-b

Vazquez-Anaya G, Martinez B, Sonanez-Organis JG, Nakano D, Nishiyama A, Ortiz RM (2017): Exogenous thyroxine improves glucose intolerance in insulin-resistant rats. J. Endocrinol. 232, 501-511 https://doi.org/10.1530/JOE-16-0428

Vidal-Puig A, Solanes G, Grujic D, Flier JS, Lowell BB (1997): UCP3: an uncoupling protein homologue expressed preferentially and abundantly in skeletal muscle and brown adipose tissue. Biochem. Biophys. Res. Commun. 235, 79-82 https://doi.org/10.1006/bbrc.1997.6740

Vidal-Puig AJ, Grujic D, Zhang CY, Hagen T, Boss O, Ido Y, Szczepanik A, Wade J, Mootha V, Cortright R, Muoio DM, Lowell 
BB (2000): Energy metabolism in uncoupling protein 3 gene knockout mice. J. Biol. Chem. 275, 16258-16266 https://doi.org/10.1074/jbc.M910179199

Yoshino J, Mills KF, Yoon MJ, Imai S (2011): Nicotinamide mononucleotide, a key $\mathrm{NAD}(+)$ intermediate, treats the pathophysiology of diet- and age-induced diabetes in mice. Cell Metab. 14, 528-536

https://doi.org/10.1016/j.cmet.2011.08.014

Zhou W, Gu Y, Li H, Luo M (2006): Assessing 1-h plasma glucose and shape of the glucose curve during oral glucose tolerance test. Eur. J. Endocrinol. 155, 191-197 https://doi.org/10.1530/eje.1.02188

Zisman A, Peroni OD, Abel ED, Michael MD, Mauvais-Jarvis F, Lowell BB, Wojtaszewski JF, Hirshman MF, Virkamaki A, Goodyear LJ, et al. (2000): Targeted disruption of the glucose transporter 4 selectively in muscle causes insulin resistance and glucose intolerance. Nat. Med. 6, 924-928 https://doi.org/10.1038/78693

Received: May 24, 2018

Final version accepted: July 9, 2018

First published online: November 15, 2018 